\title{
VERIFICATION OF THE HISAB EPHEMERIS SYSTEM AGAINST THE HIJRI CALENDAR LEAP YEAR PATTERN WITH CRITERIA IMKAN AL-RUKYAH MABIMS (Case Study in Kudus District)
}

\author{
Fika Afhamul Fuscha \\ Institute for Science and Religion Study \\ fikaafhamul@gmail.com
}

\section{Abstract :}

The hijri istilahi calendar has a 30-year cycle system, wherein 30 years there are 11 leap years and 19 basithoh years. In history, there are 4 kinds of variants in the placement of the leap year. This research aims to determine the leap year pattern of Kudus district in 30 years and to verify which patterns are close to the 4 kinds of variants. This study uses the Library Research method using a descriptive verification approach. This approach provides a sample of the number of days per month for 30 years using the Ephemeris reckoning system by considering the possibility of seeing the new moon based on the criteria of Imkan al-Rukyah MABIMS. If the hilal meets the MABIMS criteria, then the number of days is 29, but if not, then the number of days will be 30. Then, the number of days each month is accumulated annually and is used to verify the number of days each year on the hijriah istilahi calendar. Based on the analysis of the initial month data at the Kudus district headquarters for a period of 30 years, it turns out that in the period of $1411 \mathrm{H}$ to $1440 \mathrm{H}$, the spread pattern of leap years is closer to pattern IV. There are 5 years whose leap is the same as the IV pattern, namely $2,8,16,24$, and 30.

Keywords : Hisab Ephemeris, Hijriah Istilahi, Imkan Al-Rukyah MABIMS

Abstrak :

Kalender hijriah istilahi mempunyai sistem siklus 30 tahunan, dimana dalam 30 tahun terdapat 11 tahun kabisat dan 19 tahun basithoh. Dalam sejarah terdapat 4 macam varian dalam peletakan tahun kabisatnya. Tujuan dari penelitian ini adalah untuk menentukan pola tahun kabisat kabupaten Kudus dalam kurun waktu 30 
tahun dan memverifikasi pola mana yang mendekati 4 macam varian tersebut. Penelitian ini menggunakan metode Library Research dengan menggunakan pendekatan deskriptif verifikatif yakni penulis memberikan sampel jumlah hari tiap bulan selama 30 tahun menggunakan sistem hisab Ephemeris dengan mempertimbangkan kemungkinan bisa dilihatnya hilal berdasarkan kriteria Imkan al-Rukyah MABIMS. Apabila hilal memenuhi kriteria MABIMS maka jumlah hari 29, namun apabila tidak, maka jumlah hari akan 30. Kemudian, jumlah hari tiap bulan ini diakumulasi setiap tahunnya dan dipakai untuk memverifikasi jumlah hari tiap tahun dikalender hijriah istilahi. Berdasarkan analisis terhadap data awal bulan pada markas kabupaten Kudus selama kurun waktu 30 tahun, ternyata dalam rentang waktu $1411 \mathrm{H}$ sampai $1440 \mathrm{H}$, pola penyebaran tahun kabisat lebih mendekati kepada pola IV. Tedapat 5 tahun yang kabisatnya sama dengan pola IV yaitu 2, 8, 16, 24, dan 30.

Kata Kunci : Hisab Ephemeris, Hijriah Istilahi, Imkan Al-Rukyah MABIMS

\section{A. Introduction}

The hijriah istilahi calendar system or commonly known as the arimatic Islamic calendar ${ }^{1}$ has an important role in the Islamic calendar system in the past. This calendar is usually used for civil purposes, not for religious purposes. One group that uses this calendar is Syi'ah Imamiyah ${ }^{2}$ (Ithna Asyariah). However, some groups use this calendar for religious purposes as well Syi'ah Sab'iyyah ${ }^{3}$ (Ismailiyah). ${ }^{4}$

This Islamic arithmetic calendar has a cycle of 30 years. In this cycle there are 19 basithoh years and 11 leap years. ${ }^{5}$ This means that in 30 years (360 months) the number of days is $(30 \times 354)+11=10631$ days. The one-month average equals $10631 / 360=$ 29.530336 days. This value is very close to a synodic month of 29.530589 days. $^{6}$

Until now, there are 4 kinds of variants or rules in laying out leap year patterns. ${ }^{7}$ Pattern I is used by Kushyar ibn Labban ${ }^{8}$, Ulugh Beg', Taqiy ad-Din Muhammad ibn

\footnotetext{
${ }^{1}$ Arithmetic is a sequence or sequence that has a constant difference between successive terms. See: Ehsan Hidayat, "Penentuan Jumlah Gerhana Matahari Dengan Argumen Lintang Bulan Dan Teori Aritmatika,” MIYAH: Jurnal Studi Islam Vol. 16, no. No. 1 (2020): 65.

${ }^{2}$ Syi'ah Imamiyah (Ithna Asy'ariah) is syiah which makes 12 imams as the basis of their faith. lihat: Hasnah Nasution, "Pemikiran Kalam Syi'ah Imamiyah,” Analytica Islamica Vol. 4, no. 1 (2015): 33.

${ }^{3}$ Syi'ah Sab'iyyah (Ismailiyah) is the Syi'ah which only recognizes 7 Imams. Lihat: Nasution, 33.

${ }^{4}$ Ahmad Musonnif, "Pemikiran Shi'ah Ismailiyah Tentang Kalender Islam (Tinjauan Atas Sistem Kalender Hisabi Dinasti Fatimiyah),” Kontemplasi: Jurnal Ilmu-Ilmu Ushuluddin Vol 4, no. 2 (2016): 232.

${ }^{5}$ Muh. Rasywan Syarif, "Diskursus Perkembangan Formulasi Kalender Hijriah,” ElFalaky: Jurnal Ilmu Falak Vol. 2, no. 1 (2018): 53.

${ }^{6}$ Rinto Anugraha, Mekanika Benda Langit (Yogyakarta: Universitas Gadjah Mada, 2012), 15.

${ }^{7}$ M.G. Rashed, M.G. Moklof, and Alaa E. Hamza, "Investigation the Arithmetical or Tabular Islamic Calendar," NRIAG Journal of Astronomy and Geophysics 7, no. 1 (2018): 21.
} 
Ma'ruf $^{10}$. Pattern II is used by al-Fazari ${ }^{11}$, al-Khawarizmi ${ }^{12}$, al-Battani ${ }^{13}$, Toledan Tables, Alfonsine Table, MS Hijri Calender. The pattern I is used at Fathimiyyah Calendar ${ }^{14}$, Ibn al-Ajdabi. The pattern I is used by Habasy al-Hasib, al-Biruni ${ }^{15}$, Elias from Nisibis. ${ }^{16}$

From several literature studies that have been researched, the author found several works that are still related to the arithmetic Islamic calendar system, including a journal compiled by Ahmad Musonnif from IAIN Tulungagung entitled "Shi'ah Ismaili Thought About the Islamic Calendar: An Overview of the Dynastic Hisabi Calendar

${ }^{8}$ Kushar Ibn Labban is an astronomer and mathematician from the region of Gilan (Iran) who lived about 10 centuries ago. One of the important achievements in the mathematical science of astronomy is improving Ptolemy's interpolation scheme to find the ecliptic longitude of the planets. See: Mohammad Bagheri, "Kushyar Ibn Labban's Scientific Legacy," in Astronomical Heritage of the Middle East, ed. Sona V Farmanyan et al., vol. 520, Astronomical Society of the Pacific Conference Series, 2019, 185.

9 The full name of Ulugh Beg is Mohammad Taragae Ulugh Beg. The area west of Ulugh Beg is known as Tamerlane. Ulugh beg was born in Sultaniya (Iran) on March 22, 1394 AD and died October 27, 1449 AD in Samarkand, Uzbekistan. Ulugh Beg is known as the founder of the observatory as well as an astronomer. See: Jean Pierre. Luminet, "Ulugh Beg, Prince of Stars," ArXiv E-Prints, April 2018, 2-7.

${ }^{10}$ Taqi ad-Din Muhammda Ibn Ma'ruf was born in Damascus in 1526. Taqi ad-Din is a scientist who made a major contribution to the development of mathematics, astronomy, optics, and mechanics to this day.. See: Anis Nurashikin Nordin, "Regenerating Muslim Inventors - The Present Future," 'Ulum Islamiyyah: The Malaysian Journal of Islamic Sciences Vol. 31 (2020): 8.

${ }^{11}$ The full name of al-Fazari is Abu Ishaq Muhammad bin Ibrahim al-Fazari. Al-Fazari is an expert in astronomy who came from Persia and lived during the Abbasid dynasty in the era of the Caliph Abu Ja'far alMansur. Al-Fazari is one of the first Muslim scientists to make astrolabe in the Middle East. Al-Fazari died in 180 H/796 . See: Fathor Rausi, "Astrolabe; Instrumen Astronomi Klasik Dan Kontribusinya Dalam Hisab Rukyat,” ElFalaky: Jurnal Ilmu Falak Vol. 3, no. 2 (2019): 125.

${ }^{12}$ Al-Khawarizmi has a full name Muhammad bin Musa al-Khawarizmi. Al-Khawarizmi was born in Khwarim which is now Khiva (Uzbekistan) around 780, and died in Baghdad around 850. Al-Khawarizmi is an expert in mathematics, astronomy, astrology, and geography. See: Achmad Mulyadi, "Pemikiran Al-Khawarizmi Dalam Meletakkan Dasar Pengembangan Ilmu Astronomi Islam Pendahuluan Selama Kurang Lebih 14 Abad , Peradaban Islam Dapat Berjaya Di Seantero," International Journal Ihya 'Ulum Al-Din Vol. 20, no. 1 (2018): 65.

${ }^{13}$ Full name of al-Battani is Abu Abdullah Muhammad ibn Jabir ibn Sinan ar-Raqqi al-Harrani asSabi' al-Battani. Al-Battani was born in Harran near Urfa. Al-Battani is a mathematician and astronomer from Arabia, one of his great achievements is 1 solar year is equal to 365 days 5 hours, 46 minutes and 24 seconds. See: Nur Anwar, “Belajar Lebih Dari Matematikawan Muslim,” Jurnal Itqan Vol. 8, no. 2 (2017): 20.

${ }^{14}$ Fatimiyyah Calender is a calendar made by the Fatimid dynasty, which is based on the arithmetic system, not based on the observation of the new moon. See: Musonnif, "Pemikiran Shi'ah Ismailiyah Tentang Kalender Islam (Tinjauan Atas Sistem Kalender Hisabi Dinasti Fatimiyah),” 236.

${ }^{15}$ Abu Raihan al-Biruni as known as al-Biruni is a Persian mathematician, astronomer, physicist, scholar, encyclopedia writer, historian, philosopher, pharmacist, and teacher who contributed a lot to the fields of mathematics, philosophy, medicine. Al-Biruni was born 5 September 973 in Khawarazmi, Turkmenistan in the Aral lake region in Central Asia, and died on 13 December 1048. See: Anwar, "Belajar Lebih Dari Matematikawan Muslim,” 22.

${ }^{16}$ Robert Harry Van Gent, "The Arithmetical or Tabular Islamic Calender," accessed November 11, 2020, https://webspace.science.uu.nl/ gent0113/islam/islam_tabcal_variants.htm. 
System. Fatimid ". The journal proves that the Fatimid calendar emerged as a means of identity politics or a distinction between Sunni and other Shi'a groups. ${ }^{17}$

Then, the second work is the journal from M. G. Rashed $^{18}$, M.G. Moklof ${ }^{19}$, Alaa E. Hamza ${ }^{20}$ that the title is "Investigation the Arithmetical or Tabular Islamic Calendar". The research produces formulas or algorithms that can be used to determine whether the year is a leap (kabisat) or basithoh. ${ }^{21}$

The third work is Hisab Arithmetic (The Epistemological Study of Ma'sum bin Ali's Thought in the Badi'ah al-Misal Book) compiled by M. Rifa Jamaludin Nasir. This journal discusses arithmetic calculations in the book Badi'ah al-Misal by KH. Ma'sum bin $\mathrm{Ali}^{22}$

In this study, the author will discuss the leap year pattern of Kudus district using the Ephemeris reckoning system based on the Imkan al-Rukyah MABIMS criteria. Next, verify the leap patterns that are close to the 4 kinds of variants. The purpose of this study is to determine the pattern of leap years based on the Imkan al-Rukyah MABIMS criteria and to verify which patterns are close to the 4 kinds of variants.

\section{B. Research Methodology}

In this study, the authors used a library research method with a descriptive verification approach. This is because in this study the authors explored the leap year pattern in the 30-year cycle using the Ephemeris reckoning system. Therefore, the primary data source used is the Ministry of Religion's Ephemeris. To obtain the data in this study, the authors provided a sample of the number of days for 30 years in the Kudus district using the Ephemeris reckoning system by considering the possibility of seeing hilal based on the criteria of Imkan al-Rukyah MABIMS. If the hilal meets the criteria of Imkan al-Rukyah MABIMS, the number of days is 29 , but if not, then the number of days will be 30 . Then the number of days per month is accumulated, if the

\footnotetext{
${ }^{17}$ Musonnif, "Pemikiran Shi'ah Ismailiyah Tentang Kalender Islam (Tinjauan Atas Sistem Kalender Hisabi Dinasti Fatimiyah),” 231.

${ }^{18}$ National Research Institute of Astronomy and Geophysics (NRIAG), Egypt.

${ }^{19}$ Ministry of Education, Egypt.

${ }^{20}$ Faculty of Science, Cairo University, Egypt.

${ }^{21}$ Rashed, Moklof, and Hamza, "Investigation the Arithmetical or Tabular Islamic Calendar," 20.

${ }^{22}$ M Rifa Jamaludin Nasir, "Hisab Aritmatik (Kajian Epistemologi Atas Pemikiran Ma'şum Bin Ali Dalam Kitab Bad i'ah Al-Mitsal),” AL-AFAQ: Jurnal Ilmu Falak Dan Astronomi Vol. 1, no. 1 (2019): 13.
} 
number of days per year is 355 , then that year is a leap year. Conversely, if the number of days per year is 354 , then that year is a basithoh year. After all these data are collected, the data is then analyzed to determine which pattern is close to the 4 variants of the leap year pattern.

\section{Result and Discussion}

\section{C.1. Hijriah Istilahi Calendar}

Hijriah istilahi calendar The term Hijriah calendar or commonly known as the Islamic arithmetic calendar is an Islamic calendar that is arranged by setting the days of the month for 30 and 29 consecutive days. ${ }^{23}$ Hijriah istilahi calendar compiled based on arithmetic calculations, not based on certain criteria or hilal observations. Therefore, this calendar may be one day different from the calendar based on hilal observation.

In this calendar, on an odd month, the number of days in a month is always 30 days. Meanwhile, in even months, the number of days in a month is always 29 days, except for the 12 th month for leap years. ${ }^{24}$ So that the following table can be made:

\begin{tabular}{ccc}
\hline NO & MONTH & AGE \\
\hline 1 & Muharam & 30 \\
\hline 2 & Safar & 29 \\
\hline 3 & Rabiulawal & 30 \\
\hline 4 & Rabiulakhir & 29 \\
\hline 5 & Jumadilawal & 30 \\
\hline 6 & Jumadilakhir & 29 \\
\hline 7 & Rajab & 30 \\
\hline 8 & Syakban & 29 \\
\hline 9 & Ramadan & 30 \\
\hline 10 & Syawal & 29 \\
\hline 11 & Zulkaidah & 30 \\
\hline 12 & Zulhijah & $29 / 30$ \\
\hline
\end{tabular}

${ }^{23}$ Anugraha, Mekanika Benda Langit, 14.

${ }^{24}$ Muhammad Himmatur Riza, "Kriteria Kalender Hijriyah Global Tunggal Turki 2016 Perspektif Tim Hisab Rukyat Kementrian Agama RI,” ElFalaky: Jurnal Ilmu Falak 2, no. 1 (2018): 35. 
The names of the hijri months in the table above have changed four times to date, this has been explained by al-Biruni as quoted by Ali Hasan Musa, we can illustrate the names of these months as follows: ${ }^{25}$

\begin{tabular}{ccccc}
\hline \multicolumn{5}{c}{ NAME OF HIJRIAH MONTH } \\
\hline NO & I & II & III & IV \\
\hline 1 & Natiq & Mujab & Al-Mu'tamar & Muharam \\
\hline 2 & Thaqil & Mujar & Najir & Safar \\
\hline 3 & Thaliq & Murad & Khawan & Rabiulawal \\
\hline 4 & Najir & Malzam & Sawan & Rabiulakhir \\
\hline 5 & Samah & Masdar & Hantam & Jumadilawal \\
\hline 6 & Amnah & Hubar & Zubar & Jumadilakhir \\
\hline 7 & Ahlak & Hubal & Al-Asam & Rajab \\
\hline 8 & Kasa' & Muha' & 'Adil & Syakban \\
\hline 9 & Zahir & Dimar & Nafiq & Ramadan \\
\hline 10 & Bart & Dabir & Waghil & Syawal \\
\hline 11 & Harf & Hifal & Hawagh & Zulkaidah \\
\hline 12 & Na's & Musbal & Burak & Zulhijah \\
\hline
\end{tabular}

The naming of the moon as we find it today has been established by the Arabs since the end of the fifth century AD based on natural phenomena that occur. $^{26}$

Muharram is the first month. It is named the month of Muharram because in that month it is forbidden to carry out wars, raids, or fights. The following month, named Safar because of the name of the trade market in Yemen they always visit that month, namely Safariyan. There is also a mention that in that month, the leaves turn yellow (Shafr).

The months Rabiulawal and Rabiulakhir are the third and fourth months. The month comes from the word Rabi'(ربيع) which means spring (sprout). Then the months of Jumadilawal and Jumadilakhir, these two months coincided with winter. The month of Rajab is the seventh month. It is named the month of Rajab because the Arabs respect and glorify it. So they don't hear the sound of war that month. Therefore the month of Rajab is also called Ashom (أصم//deaf).

${ }^{25}$ J. Jayusman, "Wacana Takwim Urfi Dalam Penanggalan Islam," Jurnal Hukum Islam IAIN Pekalongan 7, no. 2 (2009): 20.

${ }^{26}$ Jayusman, 20. 
The eighth month is the month of Syakban. Syakban comes from the word Syi'b which means valley. In that month the Arabs descended into the valleys to herd livestock or cultivate crops. Next is the month of Ramadan. It is named the month of Ramadan, because it coincides with a very hot (stinging) summer.

The month of Shawwal is the tenth month. It is named the month of Shawwal, because the Arabs traveled scattered (away from their homes). Some say because they have a hunt that month. Next is the month of Zulkaidah. It was named Zulkaidah because the Arabs at that time sat relaxed, distancing themselves from fighting. Then the last month is the month of Zulhijah. The month of Zulhijah is the month when they perform Hajj. ${ }^{27}$

The composition of the hijriah istilahi calendar is fixed so that the age of the month is fixed every year. If we want to count the days and markets for a year, then we just need to count the days and the market for the beginning of Muharam. As for the following months, we can use the guidelines of the day and the market. The following is an example of calculating the day and the market in $1442 \mathrm{H}$ for one year:

\section{Muharam $1442 \mathrm{H}$}

Tam Year (Years passed)

$=1441$

Number of Days of Tam Month (Month Passed) $=0$

Date

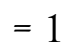

Tam Year $\rightarrow \quad 1441 \div 30$

$=48$ Cycle +1 Year

Cycle

$\rightarrow \quad 48$ Cycle X 10631

$=510.288$

Remain $\rightarrow 1$ Year X 354

$=\quad 354$

Number of Kabisat Hijriah Year

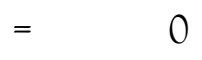

Number of day of Tam Month

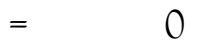

Date

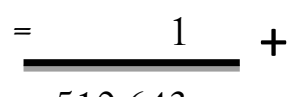

510.643

Day $\rightarrow \quad 510.643 \div 7$

$=72.949$ Remain 0 (Kamis)

Pasaran $\quad \rightarrow \quad 510.643 \div 5$

$=102.128$ Remain 3 (Pon)

${ }^{27}$ Muh. Hadi Bashori, Penanggalan Islam: Peradaban Tanpa Penanggalan, Inikah Pilihan Kita? (Jakarta: PT Elex Media Komputindo, 2013), 213-14. 
So 1 Muharam $1442 \mathrm{H}$ is on Kamis Pon

\begin{tabular}{cccccc}
\hline NO & MONTH BEGINNING & $\begin{array}{c}\text { DAY } \\
\text { CODE }\end{array}$ & $\begin{array}{c}\text { PASARAN } \\
\text { CODE }\end{array}$ & DAY & PASARAN \\
\hline 1. & 1 Muharam 1442 H & 1 & 1 & Kamis (1) & Pon (1) \\
\hline 2. & 1 Safar 1442 H & 3 & 1 & Sabtu (3) & Pon (1) \\
\hline 3. & 1 Rabiulawal 1442 H & 4 & 5 & Ahad (4) & Pahing (5) \\
\hline 4. & 1 Rabiulakhir 1442 H & 6 & 5 & Selasa (6) & Pahing (5) \\
\hline 5. & 1 Jumadilawal 1442 H & 7 & 4 & Rabu (7) & Legi (4) \\
\hline 6. & 1 Jumadilakhir 1442 H & 2 & 4 & Jumat (2) & Legi (4) \\
\hline 7. & 1 Rajab 1442 H & 3 & 3 & Sabtu (3) & Kliwon (3) \\
\hline 8. & 1 Syakban 1442 H & 5 & 3 & Senin (5) & Kliwon (3) \\
\hline 9. & 1 Ramadan 1442 H & 6 & 2 & Selasa (6) & Wage (2) \\
\hline 10. & 1 Syawal 1442 H & 1 & 2 & Kamis (1) & Wage (2) \\
\hline 11. & 1 Zulkaidah 1442 H & 2 & 1 & Jumat (2) & Pon (1) \\
\hline 12. & 1 Zulhijah 1442 H & 4 & 1 & Ahad (4) & Pon (1) \\
\hline
\end{tabular}

\section{C.2. Pattern of Kabisat Year in Hijriah Istilahi Calendar}

The hijriah istilahi calendar system has a cycle of 30 years. In one cycle there are 11 leap years (kabisat) and 19 basithoh years. In the history of the use of the arithmetic Islamic calendar, there are 4 versions in the placement of the leap year. The 4 types of variants are as follows: ${ }^{28}$

\begin{tabular}{|c|c|c|}
\hline Type & $\begin{array}{c}\text { Kabisat year age } 355 \text { day in Siklus } 30 \\
\text { Years Cycle }\end{array}$ & Founder/User \\
\hline I & $\begin{array}{c}2,5,7,10,13,15,18,21,24,26 \\
\operatorname{dan} 29\end{array}$ & $\begin{array}{c}\text { Kushyar ibn Labban, Ulugh } \\
\text { Beg, Taqiy ad-Din } \\
\text { Muhammad ibn Ma'ruf }\end{array}$ \\
\hline II & $\begin{array}{c}2,5,7,10,13,16,18,21,24,26 \\
\operatorname{dan} 29\end{array}$ & $\begin{array}{c}\text { Al-Fazari, Al-Khawarizmi, Al- } \\
\text { Battani, Toledan Tables, Al- } \\
\text { Fonsine Tables, MS } \\
\text { HijriCalender }\end{array}$ \\
\hline III & $\begin{array}{c}2,5,8,10,13,16,19,21,24,27 \\
\operatorname{dan} 29\end{array}$ & $\begin{array}{l}\text { Kalender Fathimiyyah (juga } \\
\text { dikenal sebagai kalender } \\
\text { Misri atau kalender Buhrah), } \\
\text { Ibn al-Ajdabi }\end{array}$ \\
\hline IV & $\begin{array}{c}2,5,8,11,13,16,19,21,24,27 \\
\text { dan } 30\end{array}$ & $\begin{array}{l}\text { Habasy al-Hasib, Al-Biruni, } \\
\text { Elias dari Nisibis }\end{array}$ \\
\hline
\end{tabular}

${ }^{28}$ Gent, "The Arithmetical or Tabular Islamic Calender." 
Hijri calendar refers to the synodic period of the month. The synodic period is the length of time it takes for the moon between the new moon phase to the next new moon phase (between conjunction with the next conjunction). The average synodic month was 29.530589 or 29 days 12 hours 44 minutes 3 seconds. ${ }^{29}$ These values are the average over a synodic month. If this value is accumulated during one hijri year, then the value becomes $29.530589 \times 12$ months $=354.367068$ or 354 days 8 hours 48 minutes 35 seconds. So during one hijri year, there is still an excess of 8 hours 48 minutes. This figure, if accumulated every year, will produce the following conclusions:

\begin{tabular}{cccc}
\hline Year & Day & Hour & Minute \\
\hline 1 & 0 & 8 & 48 \\
\hline 2 & 0 & 17 & 36 \\
\hline 3 & 1 & 2 & 24 \\
\hline 4 & 1 & 11 & 12 \\
\hline 5 & 1 & 20 & 0 \\
\hline 6 & 2 & 4 & 48 \\
\hline 7 & 2 & 13 & 36 \\
\hline 8 & 2 & 22 & 26 \\
\hline 9 & 3 & 7 & 12 \\
\hline 10 & 3 & 16 & 6 \\
\hline 11 & 4 & 0 & 48 \\
\hline 12 & 4 & 9 & 36 \\
\hline 13 & 4 & 18 & 24 \\
\hline 14 & 5 & 3 & 12 \\
\hline 15 & 5 & 12 & 0 \\
\hline
\end{tabular}

\begin{tabular}{cccc}
\hline Year & Day & Hour & Minute \\
\hline 16 & 5 & 20 & 48 \\
\hline 17 & 6 & 5 & 36 \\
\hline 18 & 6 & 14 & 24 \\
\hline 19 & 6 & 23 & 12 \\
\hline 20 & 7 & 8 & 0 \\
\hline 21 & 7 & 16 & 48 \\
\hline 22 & 8 & 1 & 36 \\
\hline 23 & 8 & 10 & 24 \\
\hline 24 & 8 & 19 & 12 \\
\hline 25 & 9 & 4 & 0 \\
\hline 26 & 9 & 12 & 48 \\
\hline 27 & 9 & 21 & 36 \\
\hline 28 & 10 & 6 & 24 \\
\hline 29 & 10 & 15 & 12 \\
\hline 30 & 11 & 0 & 0 \\
\hline 4 & & &
\end{tabular}

From this table, we can conclude 4 different variants of the leap year pattern. Each leap year pattern has its characteristics in the distribution of the leap year.

In pattern I, the leap lies in years 2, 5, 7, 10, 13, 15, 18, 21, 24, 26, and 29. This system is widely adopted by classical books in Indonesia, such as Syamsul Hilal, Ad-Durus al-Falakiyah, Badi'ah al-Mitsal, al-Khulashah al-Wafiyyah. In the book

${ }^{29}$ Alaik Ridhallah, "Sistem Penaggalan Baha'i Persfektif Astronomi," AL-AFAQ: Jurnal Ilmu Falak Dan Astronomi Vol. 2, no. 1 (2020): 63-64. 
of Syamsul Hilal Juz I, These leap years are collected in stanzas written in jumali letters as follows:

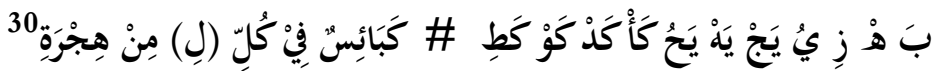

Apart from the above verse, leap years in this pattern are also found in other verses, where the dotted letters are leap years, and those without dots are basithoh years.

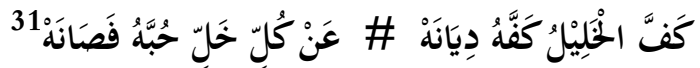

In this pattern, the year will be considered a leap (kabisat) if the accumulated remainder is equal to or has exceeded 12 hours. If there are 2 years where the remaining accumulated hours are the same or have exceeded 12 hours, then the year that is considered leap is the closest accumulated hours remaining.

\begin{tabular}{ccccc}
\hline Year & Day & Hour & Minute & Exp \\
\hline 1 & 0 & 8 & 48 & \\
\hline 2 & 0 & 17 & 36 & $\mathrm{~K}$ \\
\hline 3 & 1 & 2 & 24 & \\
\hline 4 & 1 & 11 & 12 & \\
\hline 5 & 1 & 20 & 0 & $\mathrm{~K}$ \\
\hline 6 & 2 & 4 & 48 & \\
\hline 7 & 2 & 13 & 36 & $\mathrm{~K}$ \\
\hline 8 & 2 & 22 & 26 & \\
\hline 9 & 3 & 7 & 12 & \\
\hline 10 & 3 & 16 & 6 & $\mathrm{~K}$ \\
\hline 11 & 4 & 0 & 48 & \\
\hline 12 & 4 & 9 & 36 & \\
\hline 13 & 4 & 18 & 24 & $\mathrm{~K}$ \\
\hline 14 & 5 & 3 & 12 & \\
\hline 15 & 5 & 12 & 0 & $\mathrm{~K}$ \\
\hline & & & &
\end{tabular}

\begin{tabular}{ccccc}
\hline Year & Day & Hour & Minute & Exp \\
\hline 16 & 5 & 20 & 48 & \\
\hline 17 & 6 & 5 & 36 & \\
\hline 18 & 6 & 14 & 24 & $\mathrm{~K}$ \\
\hline 19 & 6 & 23 & 12 & \\
\hline 20 & 7 & 8 & 0 & \\
\hline 21 & 7 & 16 & 48 & $\mathrm{~K}$ \\
\hline 22 & 8 & 1 & 36 & \\
\hline 23 & 8 & 10 & 24 & \\
\hline 24 & 8 & 19 & 12 & $\mathrm{~K}$ \\
\hline 25 & 9 & 4 & 0 & \\
\hline 26 & 9 & 12 & 48 & $\mathrm{~K}$ \\
\hline 27 & 9 & 21 & 36 & \\
\hline 28 & 10 & 6 & 24 & \\
\hline 29 & 10 & 15 & 12 & $\mathrm{~K}$ \\
\hline 30 & 11 & 0 & 0 & \\
\hline & & & &
\end{tabular}

In pattern II, the leap lies in years 2, 5, 7, 10, 13, 16, 18, 21, 24, 26, and 29. This system is used by Al-Fazari, Al-Khawarizmi, Al-Battani, Toledan Tables, AlFonsine Tables, MS HijriCalender. In this pattern, the year is considered a leap (kabisat) when the accumulated residual exceeds 12 hours. If there are 2 years

\footnotetext{
${ }^{30}$ Noor Ahmad SS and Abu Syaiful Mujab, Risalah Syamsul Hilal Juz I (Kudus: Madrasah Tasywiquth Thullab Salafiyah Kudus, n.d.), 4.

${ }^{31}$ SS and Mujab, 4.
} 
where the remaining accumulated hours have exceeded 12 hours, then the year that is considered leap is the closest accumulated hours remaining.

\begin{tabular}{ccccc}
\hline Year & Day & Hour & Minute & Exp \\
\hline 1 & 0 & 8 & 48 & \\
\hline 2 & 0 & 17 & 36 & $\mathrm{~K}$ \\
\hline 3 & 1 & 2 & 24 & \\
\hline 4 & 1 & 11 & 12 & \\
\hline 5 & 1 & 20 & 0 & $\mathrm{~K}$ \\
\hline 6 & 2 & 4 & 48 & \\
\hline 7 & 2 & 13 & 36 & $\mathrm{~K}$ \\
\hline 8 & 2 & 22 & 26 & \\
\hline 9 & 3 & 7 & 12 & \\
\hline 10 & 3 & 16 & 6 & $\mathrm{~K}$ \\
\hline 11 & 4 & 0 & 48 & \\
\hline 12 & 4 & 9 & 36 & \\
\hline 13 & 4 & 18 & 24 & $\mathrm{~K}$ \\
\hline 14 & 5 & 3 & 12 & \\
\hline 15 & 5 & 12 & 0 & \\
\hline & & & &
\end{tabular}

\begin{tabular}{ccccc}
\hline Year & Day & Hour & Minute & Exp \\
\hline 16 & 5 & 20 & 48 & $\mathrm{~K}$ \\
\hline 17 & 6 & 5 & 36 & \\
\hline 18 & 6 & 14 & 24 & $\mathrm{~K}$ \\
\hline 19 & 6 & 23 & 12 & \\
\hline 20 & 7 & 8 & 0 & \\
\hline 21 & 7 & 16 & 48 & $\mathrm{~K}$ \\
\hline 22 & 8 & 1 & 36 & \\
\hline 23 & 8 & 10 & 24 & \\
\hline 24 & 8 & 19 & 12 & $\mathrm{~K}$ \\
\hline 25 & 9 & 4 & 0 & \\
\hline 26 & 9 & 12 & 48 & $\mathrm{~K}$ \\
\hline 27 & 9 & 21 & 36 & \\
\hline 28 & 10 & 6 & 24 & \\
\hline 29 & 10 & 15 & 12 & $\mathrm{~K}$ \\
\hline 30 & 11 & 0 & 0 & \\
\hline & & & &
\end{tabular}

In pattern III, the leap years are in years 2, 5, 8, 10, 13, 16, 19, 21, 24, 27, and 29. This system is used by the Fathimiyyah calendar (also known as the Misri calendar or the Buhrah calendar), Ibn al-Ajdabi. In this pattern, the year is considered a leap (kabisat) when the accumulated residual exceeds 15 hours. If there are 2 years where the remaining accumulated hours have exceeded 15 hours, then the year that is considered leap is the closest accumulated hours remaining.

\begin{tabular}{ccccc}
\hline Year & Day & Hour & Minute & Exp \\
\hline 1 & 0 & 8 & 48 & \\
\hline 2 & 0 & 17 & 36 & $\mathrm{~K}$ \\
\hline 3 & 1 & 2 & 24 & \\
\hline 4 & 1 & 11 & 12 & \\
\hline 5 & 1 & 20 & 0 & $\mathrm{~K}$ \\
\hline 6 & 2 & 4 & 48 & \\
\hline 7 & 2 & 13 & 36 & \\
\hline 8 & 2 & 22 & 26 & $\mathrm{~K}$ \\
\hline 9 & 3 & 7 & 12 & \\
\hline 10 & 3 & 16 & 6 & $\mathrm{~K}$ \\
\hline 11 & 4 & 0 & 48 & \\
\hline 12 & 4 & 9 & 36 & \\
\hline 13 & 4 & 18 & 24 & $\mathrm{~K}$ \\
\hline 14 & 5 & 3 & 12 & \\
\hline 15 & 5 & 12 & 0 & \\
\hline & & & &
\end{tabular}

\begin{tabular}{ccccc}
\hline Year & Day & Hour & Minute & Exp \\
\hline 16 & 5 & 20 & 48 & $\mathrm{~K}$ \\
\hline 17 & 6 & 5 & 36 & \\
\hline 18 & 6 & 14 & 24 & \\
\hline 19 & 6 & 23 & 12 & $\mathrm{~K}$ \\
\hline 20 & 7 & 8 & 0 & \\
\hline 21 & 7 & 16 & 48 & $\mathrm{~K}$ \\
\hline 22 & 8 & 1 & 36 & \\
\hline 23 & 8 & 10 & 24 & \\
\hline 24 & 8 & 19 & 12 & $\mathrm{~K}$ \\
\hline 25 & 9 & 4 & 0 & \\
\hline 26 & 9 & 12 & 48 & \\
\hline 27 & 9 & 21 & 36 & $\mathrm{~K}$ \\
\hline 28 & 10 & 6 & 24 & \\
\hline 29 & 10 & 15 & 12 & $\mathrm{~K}$ \\
\hline 30 & 11 & 0 & 0 & \\
\hline
\end{tabular}


In pattern IV, the leap lies in years $2,5,8,11,13,16,19,21,24,27$, and 30. This system is used by Habasy al-Hasib, Al-Biruni, Elias of Nisibis. In this pattern, the year is considered a leap (kabisat) when the accumulated residual exceeds 16 hours and 30 minutes. If there are 2 years where the remaining accumulated hours have exceeded 16 hours and 30 minutes, then the year that is considered leap is the closest accumulated hours remaining.

\begin{tabular}{ccccc}
\hline Year & Day & Hour & Minute & Exp \\
\hline 1 & 0 & 8 & 48 & \\
\hline 2 & 0 & 17 & 36 & $\mathrm{~K}$ \\
\hline 3 & 1 & 2 & 24 & \\
\hline 4 & 1 & 11 & 12 & \\
\hline 5 & 1 & 20 & 0 & $\mathrm{~K}$ \\
\hline 6 & 2 & 4 & 48 & \\
\hline 7 & 2 & 13 & 36 & \\
\hline 8 & 2 & 22 & 26 & $\mathrm{~K}$ \\
\hline 9 & 3 & 7 & 12 & \\
\hline 10 & 3 & 16 & 6 & \\
\hline 11 & 4 & 0 & 48 & $\mathrm{~K}$ \\
\hline 12 & 4 & 9 & 36 & \\
\hline 13 & 4 & 18 & 24 & $\mathrm{~K}$ \\
\hline 14 & 5 & 3 & 12 & \\
\hline 15 & 5 & 12 & 0 & \\
\hline & & & &
\end{tabular}

\begin{tabular}{ccccc}
\hline Year & Day & Hour & Minute & Exp \\
\hline 16 & 5 & 20 & 48 & $\mathrm{~K}$ \\
\hline 17 & 6 & 5 & 36 & \\
\hline 18 & 6 & 14 & 24 & \\
\hline 19 & 6 & 23 & 12 & $\mathrm{~K}$ \\
\hline 20 & 7 & 8 & 0 & \\
\hline 21 & 7 & 16 & 48 & $\mathrm{~K}$ \\
\hline 22 & 8 & 1 & 36 & \\
\hline 23 & 8 & 10 & 24 & \\
\hline 24 & 8 & 19 & 12 & $\mathrm{~K}$ \\
\hline 25 & 9 & 4 & 0 & \\
\hline 26 & 9 & 12 & 48 & \\
\hline 27 & 9 & 21 & 36 & $\mathrm{~K}$ \\
\hline 28 & 10 & 6 & 24 & \\
\hline 29 & 10 & 15 & 12 & \\
\hline 30 & 11 & 0 & 0 & $\mathrm{~K}$ \\
\hline
\end{tabular}

\section{C.3. Hisab Ephemeris System}

Etymologically, the word hisab comes from Arabic (حسَبَ - يَكْسُبُ - حِسَابًا) which mean al-Adad wa al-Ihsha', number or count. ${ }^{32}$ In English, this word is called arithmetic, which means arithmetic. ${ }^{33}$

One example of the word "hisab" in the verse of the Koran which means calculation, which is more devoted to the science of astronomy (falak), is found in QS. Al-Isra ayat 12:

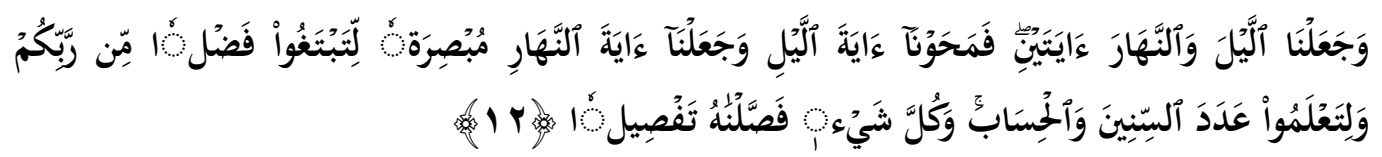

\footnotetext{
${ }^{32}$ Ahmad Warson Munawwir, Al-Munawwir: Kamus Arab Indonesia (Surabaya: Pustaka Progesif, 1997),
} 261.

${ }^{33}$ John M Echols, Kamus Inggris Indonesia (Jakarta: PT. Gramedia, 2005), 37. 
"We made the day and night as two signs. So We made the sign of the night devoid of light, and We made the sign of the day 'perfectly' bright, so that you may seek the bounty of your Lord and know the number of years and calculation 'of time'. And We have explained everything in detail.." ${ }^{34}$

The hadiths related to the determination of the beginning of the Kamariyyah month (beginning and end of Ramadan) are all general and multiinterpretations, including::

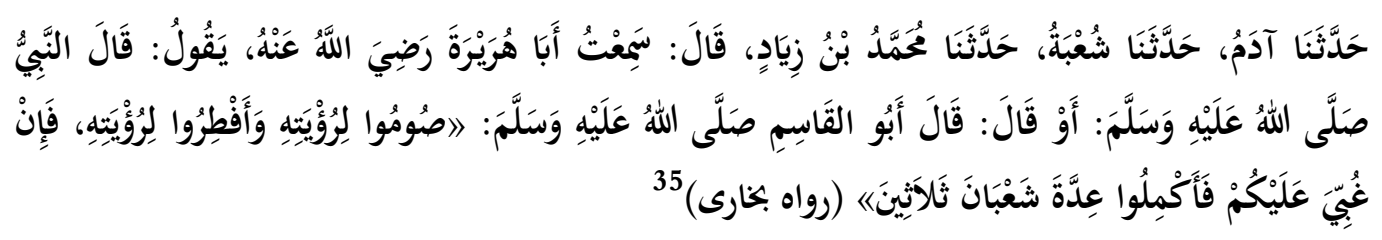

"Adam has told us, Syu'bah has told us, Muhammad bin Ziyad has told us, said: I heard Abu Hurairah say: Rasulullah said: Abu Qosim said: Fast you because you see the new moon and break your fast (Eid) because seen hilal. If the new moon is covered with clouds over you, then complete the number of months of Sha'ban thirty". (Hadits Riwayat Bukhori)

This hadith instructs to start and end the fast of Ramadan with rukyat and if the weather is cloudy so that you cannot see the new moon, then an estimate should be made (calculation/forecast). ${ }^{36}$

In the study of Falak science, the determining of the beginning of the lunar month can be classified in several methods:

1. Hisab Urfi/Hijriah Istilahi

Hisab urfi/hijriah istilahi system is a calculation system based on the moon's cycle based on the apparent motion of the moon. The urfi hisab system determines the days of the month as 30 and 29 days respectively.

Hisab urfi uses a calendar arithmetic calculation system, so that each year has a fixed number of days. In odd months the number of days is 30 days, while for even months the number of days is 29 days. ${ }^{37}$

2. Hisab Taqribi

\footnotetext{
34 Yayasan Penyelenggara Penterjemah Mushaf Al-Quran Departemen Agama RI, Al-Qur'an Dan Terjemah Juz 1-Juz 30 (Surabaya: Terbit Terang, 2002), 385-86.

${ }^{35}$ Muhammad bin Ismail Abu Abdullah Al-Bukhori, Shohih Bukhori, (Beirut: Dar Thuq al-Najah, 1422 H), J. 3, hlm. 27.

${ }^{36}$ Syamsul Anwar, Hisab Awal Bulan Kamariah (Yogyakarta: Suara Muhammadiah, 2009), 2.

${ }^{37}$ Syarif, "Diskursus Perkembangan Formulasi Kalender Hijriah," 52.
} 
Hisab taqribi system is a calculation system with a low level of accuracy because the database that is used as a reference is $\mathrm{Zij}$ (astronomical table) Ulugh Beg and in carrying out his observations based on the geocentric theory of Ptolemy. ${ }^{38}$

3. Hisab Hakiki

Hisab hakiki system is a calculation system that has a high level of accuracy but is still classified as a classic. Because the data that is used as the basis for the calculation is still static. This calculating has adopted the spherical trigonometry formula. ${ }^{39}$

\section{Hisab Kontemporer}

Hisab Kontemporer system is a calculation system that has a high degree of accuracy using contemporary dynamic data. ${ }^{40}$

Ephemeris is a collection of astronomical data showing the positions of celestial bodies. ${ }^{41}$ Hisab ephemeris system is an astronomical calculation system in which the astronomical data (ephemeris) of the Sun and Moon used is taken from the WinHisab program. In addition, the ephemeris data is also published by the Ministry of Religion of the Republic of Indonesia each year in the form of a book entitled Ephemeris Hisab Rukyat. ${ }^{42}$

There are various astronomical calculation methods that we can use to find out data on the ephemeris of the Sun and Moon, from low accuracy to high accuracy. One of the methods of calculating the ephemeris data of the Sun and Moon that is classified as a high accuracy computing method is the calculation algorithm compiled by Jean Meeus. ${ }^{43}$ In his book entitled Astronomical Algorithms.

${ }^{38}$ Bashori, Penanggalan Islam: Peradaban Tanpa Penanggalan, Inikah Pilihan Kita?, 118.

${ }^{39}$ Bashori, 119.

${ }^{40}$ Bashori, 120.

41 Zul Amri Fathinul Inshafi, "Aplikasi Data Ephemeris Matahari Dan Bulan Berdasarkan Perhitungan Jean Meeus Pada Smartphone Android” (Universitas Islam Negeri Walisongo, 2016), 5.

${ }^{42}$ Muhyiddin Khazin, Ilmu Falak: Dalam Teori Dan Praktik (Yogyakarta: Buana Pustaka, 2008), 37.

${ }^{43}$ Jean Meeus adalah seorang Astronom yang lahir pada tahun 1928 di Belgia. Ia mendapat julukan Master of Astronomical Calculations, karena sering melakukan perhitungan-perhitungan terhadap kejadian- 
Astronomical Algorithms are the result of a reduction from the calculation of VSOP $87^{44}$ and ELP-2000/82 $2^{45}$ which is higher in accuracy and more complex. VSOP87 is the calculation reference for solar data. Meanwhile, ELP-2000/82 is a calculation reference for Moon data.

The calculation algorithm compiled by Jean Meeus can produce accurate data on the position of the Sun and the Moon, with an error rate of not more than 1-second longitude in the period between -2000 to +6000 (about 8000 years). ${ }^{46}$

\section{C.4. The Criteria of Imkan al-Rukyah MABIMS}

Imkan al-Rukyah from a linguistic side, comes from the word ( - أَمْنَ - يُمْكِنُ رَأَى ) (إْْكَنَا

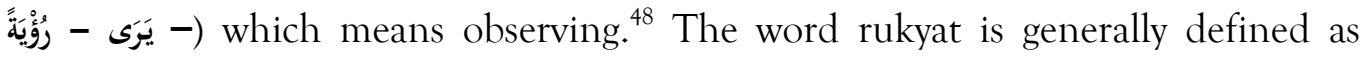
observing using the eyes of the head. Whereas, in astronomy, rukyat is known as observation. $^{49}$

The term of ru'yah al-hilal, in the context of determining the beginning of the Kamariyah month, is seeing the new moon with the eye or by using a tool done at the end of each month or the 29th of the Kamariyah month at sunset. ${ }^{50}$ The success of the rukyat on the 29th day of the end of the lunar month is decisive in determining the start of the lunar month.

kejadian astronomi yang langka. Lihat: Jean Meeus, Mathematical Astronomy Morsels (Virginia: Willmann-Bell, Inc., 1997), iii.

${ }^{44}$ Variations Seculaires des Orbites Planetaires atau yang lebih dikenal dengan VSOP87 merupakan teori lintasan planet-planet yang dipublikasikan oleh G. Francou dab P. Bretagnon, pada tahun 1987 di Paris. VSOP87 merupakan revisi dari VSOP82. Total jumlah koreksi VSOP87 sebanyak 2425 buah. Terdiri dari 1080 koreksi untuk bujur ekliptika, 348 koreksi untuk lintang ekliptika, dan 997 koreksi untuk jarak Matahari dan Bumi. Lihat: Jean Meeus, Astronomical Alghorithms (Virginia: Willmann-Bell, Inc., 1998), 205.

${ }^{45}$ Ephemerides Lunaires Parisiennes atau yang kita kenal denan ELP-2000/82 adalah teori lintasan Bulan yang dipublikasikan oleh J. Chapront dan M. Chapront-Touze pada tahun 1983 di Paris. total koreksi dari teori ELP-2000/82 adalah sebanyak 37.862 suku koreksi. terdiri dari 20.560 koreksi Bujur Bulan, 7.684 koreksi Lintang Bulan, dan 9.618 koreksi jarak Bulan ke Bumi. Lihat: Meeus, 344.

${ }^{46}$ Meeus, 154.

${ }^{47}$ Munawwir, Al-Munawwir: Kamus Arab Indonesia, 1353.

${ }^{48}$ Munawwir, 460.

${ }^{49}$ Susiknan Azhari, Ensiklopedia Hisab Rukyat (Yogyakarta: Pustaka Pelajar, 2005), 128.

${ }^{50}$ Khazin, Ilmu Falak: Dalam Teori Dan Praktik, 173. 
According to Jumhur Ulama, the Determination of the beginning of the month of Ramadan as the month in which fasting is required and the beginning of the month of Shawwal as the start of breaking the fast of Ramadan must be by ru'yah al-hilal or see the new moon directly (empirically). ${ }^{51}$

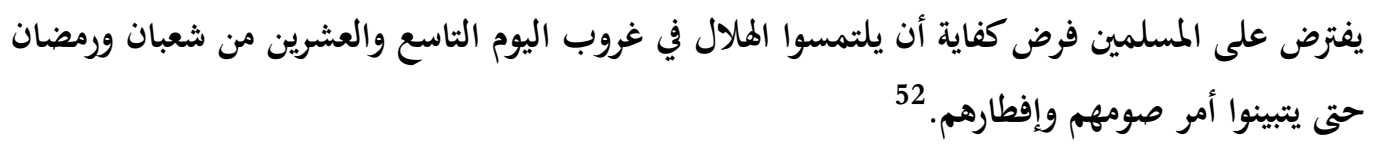

"It is obligatory for Muslims as Fardhu Kifayah to look for the new moon at sunset on the 29th of Sya'ban and Ramadan so it is clear the problem of fasting and breaking the fast." (al-Fiqhu ala al-Madzahibi al-arba'ah, Juz 1, Halaman 501).

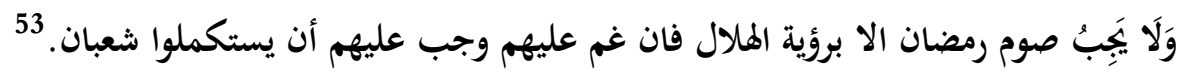

"It is not obligatory to fast for Ramadan except for the reason of rukyah al-hilal. So if the hilal is covered by a cloud for them, then it is obligatory to complete (istikmal) Sya'ban.” (al-Majmu' Syarh Al-Muhadzab, Juz VI, halaman 269).

The development of rukyah al-hilal activities is not only carried out at the end of the month of Shakban and Ramadan, but also in other months. Especially towards the beginning of the month which is related to the routine activities of religious rituals or major holidays in Islam. In fact, for researchers such as students, the rukyah al-hilal activity is carried out at the beginning of each month, which is useful as an exercise to also correct the results of hisab.

In Indonesia, the word Imkan al-Rukyah is popularly translated as "Hilal Visibility". Visibility means the state can be seen or can be observed (especially for weather conditions, objects can be seen clearly at a certain distance). Thomas Djamalauddin in his book Astronomy Gives Unification of the Ummah (Astronomi Memberi Solusi Penyatuan Umat) explains that the visibility of the

${ }^{51}$ Wahbah Az-Zuhaili, “Al-Fiqhu Al-Islami Wa Adillatuhu,” in J. II (Beirut: Dar al-Fikr, 1989), 597608.

${ }^{52}$ Al-Juzairi, “Al-Fiqhu Ala Al-Madzahibi Al-Arba’ah,” in J.I (Beirut: Dar Kutub al-Ilmiah, 2003), 501.

${ }^{53}$ Imam Abu Zakariya Muhyiddin bin Syarof An-Nawawi, "Al-Majmu' Syarh Al-Muhadzab," in J. VI (Beirut: Dar Kutub al-Ilmiah, 1996), 269. 
hilal is the appearance of the first crescent, while Imkan al-Rukyah is the possibility (hilal) can be seen. ${ }^{54}$

Imkan al-Rukyah MABIMS is the criteria for determining the beginning of the lunar month (calendar) which is determined based on the deliberation of the Ministers of Religion of Brunei Darussalam, Indonesia, Malaysia, and Singapore, and is used officially for the determination of the beginning of the lunar month on the official government calendar, on the principle that the beginning of the Islamic month (calendar) occurs if:

1) At sunset, the altitude (altitude) of the Moon is above the horizon minimum of $2^{\circ}$;

2) The angle of elongation (curvature) between the Moon and the Sun is $3^{\circ}$;

3) When the Moon sets, the minimum age of the Moon is 8 hours, calculated from the time the ijtima occurs. ${ }^{55}$

\section{C.5. Verification of Kabisat (Leap) Year Pattern}

After knowing the characteristics of each leap year pattern on the hijriah istilahi calendar, then we will discuss the leap year pattern based on the Imkan alRukyah MABIMS criteria using the Kudus district headquarters in the period $1411 \mathrm{H}$ to $1440 \mathrm{H}$ (one period / 30 years).

The Imkan al-Rukyah criterion is a calculation based on the possibility that the new moon can be observed either with the help of an optical instrument or the eye. ${ }^{56}$ MABIMS is the acronim of Menteri-mentri Agama Brunei Darussalam, Indonesia, Malaysia, dan Singapura (Ministers of Religion, Brunei Darussalam, Indonesia, Malaysia and Singapore).$^{57}$

\footnotetext{
${ }^{54}$ Thomas Djamaluddin, Astronomi Memberi Solusi Penyatuan Umat (Bandung: LAPAN, 2011), 10-11.

${ }^{55}$ Ma'rufin Sudibyo, Variasi Lokal Dalam Visibilitas Hilal: Observasi Hilal Di Indonesia Pada 2007-2009 (Yogyakarta: Lembaga Pengkajian dan Pengembangan Ilmu Falak RHI, 2012), 120.

${ }^{56}$ Siti Muslifah, "Upaya Menyikapi Perbedaan Penentuan Awal Bulan Qamariyah Di Indonesia," Azimuth: Journal of Islamic Astronomy Vol. 1, no. 1 (2020): 88.

${ }^{57}$ Arino Bemi Sado, "Imkan Al-Rukyat MABIMS Solusi Penyeragaman Kalender Hijriyah," Istinbath: Jurnal Hukum Islam Vol. 13, no. 1 (2014): 24.
} 
As a first step in verifying the leap year pattern that is close to contemporary calculations with 4 different variants of the term hijriah leap year, the author uses the Ministry of Religion's Ephemeris reckoning system with the Imkan al-Rukyah MABIMS criteria, namely a hilal height of at least 2 degrees, a minimum elongation of 3 degrees, and age. hilal for at least 8 hours. ${ }^{58}$ The samples from each month can be seen in the following table.

\begin{tabular}{|c|c|c|c|c|c|c|c|c|c|c|c|c|c|}
\hline \multirow{2}{*}{ Year } & \multicolumn{12}{|c|}{ Hijriah Month } & \multirow[t]{2}{*}{ Amount } \\
\hline & 1 & 2 & 3 & 4 & 5 & 6 & 7 & 8 & 9 & 10 & 11 & 12 & \\
\hline 1411 & 29 & 29 & 30 & 30 & 30 & 29 & 30 & 30 & 29 & 30 & 29 & 29 & 354 \\
\hline 1412 & 29 & 30 & 29 & 30 & 30 & 29 & 30 & 30 & 30 & 29 & 30 & 29 & 355 \\
\hline 1413 & 29 & 30 & 29 & 29 & 30 & 29 & 30 & 30 & 30 & 30 & 29 & 29 & 354 \\
\hline 1 & 30 & 29 & 30 & 29 & 29 & 30 & 29 & 30 & 30 & 30 & 29 & 30 & 355 \\
\hline & 29 & 30 & 29 & 30 & 29 & 29 & 30 & 29 & 30 & 30 & 29 & 30 & 354 \\
\hline 416 & 29 & 30 & 30 & 29 & 30 & 29 & 29 & 30 & 29 & 30 & 29 & 30 & 354 \\
\hline & 29 & 30 & 30 & 29 & 30 & 30 & 29 & 30 & 29 & 29 & 30 & 29 & 354 \\
\hline 18 & 30 & 29 & 30 & 29 & 30 & 30 & 29 & 30 & 30 & 29 & 30 & 29 & 355 \\
\hline & 29 & 30 & 29 & 29 & 30 & 30 & 30 & 29 & 30 & 30 & 29 & 30 & 355 \\
\hline 420 & 29 & 29 & 29 & 30 & 29 & 30 & 30 & 29 & 30 & 30 & 30 & 29 & 354 \\
\hline 1 & 30 & 29 & 29 & 29 & 30 & 29 & 30 & 29 & 30 & 30 & 30 & 29 & 354 \\
\hline 422 & 30 & 30 & 29 & 29 & 30 & 29 & 29 & 30 & 29 & 30 & 30 & 29 & 354 \\
\hline 1423 & 30 & 30 & 29 & 30 & 29 & 30 & 29 & 29 & 30 & 29 & 30 & 29 & 354 \\
\hline 1424 & 30 & 30 & 30 & 29 & 30 & 29 & 30 & 29 & 29 & 30 & 29 & 30 & 355 \\
\hline 425 & 29 & 30 & 30 & 29 & 30 & 29 & 30 & 30 & 29 & 29 & 30 & 29 & 354 \\
\hline 126 & 30 & 29 & 30 & 29 & 30 & 30 & 29 & 30 & 29 & 30 & 30 & 29 & 355 \\
\hline 427 & 29 & 30 & 29 & 30 & 29 & 30 & 29 & 30 & 30 & 29 & 30 & 30 & 355 \\
\hline & 29 & 29 & 30 & 29 & 30 & 29 & 29 & 30 & 30 & 29 & 30 & 30 & 354 \\
\hline 429 & 30 & 29 & 30 & 29 & 29 & 29 & 30 & 29 & 30 & 29 & 30 & 30 & 354 \\
\hline & 30 & 30 & 29 & 30 & 29 & 29 & 29 & 30 & 29 & 30 & 29 & 30 & 354 \\
\hline 1431 & 30 & 30 & 30 & 29 & 29 & 30 & 29 & 30 & 29 & 29 & 30 & 29 & 354 \\
\hline & 30 & 30 & 30 & 29 & 30 & 29 & 30 & 29 & 30 & 29 & 29 & 30 & 355 \\
\hline 1433 & 29 & 30 & 30 & 29 & 30 & 29 & 30 & 30 & 29 & 30 & 29 & 29 & 354 \\
\hline 1434 & 30 & 29 & 30 & 29 & 30 & 29 & 30 & 30 & 29 & 30 & 29 & 30 & 355 \\
\hline 1435 & 29 & 30 & 29 & 30 & 29 & 30 & 29 & 30 & 29 & 30 & 30 & 29 & 354 \\
\hline 1436 & 30 & 29 & 30 & 29 & 30 & 29 & 30 & 29 & 29 & 30 & 30 & 29 & 354 \\
\hline 1437 & 30 & 30 & 29 & 30 & 29 & 30 & 29 & 30 & 29 & 29 & 30 & 29 & 354 \\
\hline 1438 & 30 & 30 & 30 & 29 & 30 & 30 & 29 & 29 & 29 & 30 & 29 & 30 & 355 \\
\hline 1439 & 29 & 30 & 30 & 29 & 30 & 30 & 29 & 30 & 29 & 30 & 29 & 29 & 354 \\
\hline 1440 & 30 & 29 & 30 & 29 & 30 & 30 & 30 & 29 & 30 & 29 & 30 & 29 & 355 \\
\hline
\end{tabular}

${ }^{58}$ Ahmad Adib Rofiuddin, "Dinamika Sosial Penentuan Awal Bulan Hijriah Di Indonesia," Istinbath: Jurnal Hukum Dan Ekonomi Islam Vol. 18, no. 2 (2019): 244.

Al-Hilal: Journal of Islamic Astronomy, Vol. 3, No. 1, 2021

p-ISSN : 2775-1236 ; e-ISSN : 2775-2119 
Then the number of days per month is accumulated in one year and identified. If the number of days in a year is 354 then that year is the basithoh. Conversely, if the number of days in a year is 355 days, then that year is a Kabisat year. The accumulated data for each year can be seen in the following table.

\begin{tabular}{|c|c|c|c|c|}
\hline Year & $\begin{array}{c}\text { Number of } \\
\text { Day }\end{array}$ & Total & Type & Pattern \\
\hline 1411 & 354 & & Basithoh & \\
\hline 1412 & 355 & 709 & Kabisat & 2 \\
\hline 1413 & 354 & 1063 & Basithoh & \\
\hline 1414 & 355 & 1418 & Kabisat & 4 \\
\hline 1415 & 354 & 1772 & Basithoh & \\
\hline 1416 & 354 & 2126 & Basithoh & \\
\hline 1417 & 354 & 2480 & Basithoh & \\
\hline 1418 & 355 & 2835 & Kabisat & 8 \\
\hline 1419 & 355 & 3190 & Kabisat & 9 \\
\hline 1420 & 354 & 3544 & Basithoh & \\
\hline 1421 & 354 & 3898 & Basithoh & \\
\hline 1422 & 354 & 4252 & Basithoh & \\
\hline 1423 & 354 & 4606 & Basithoh & \\
\hline 1424 & 355 & 4961 & Kabisat & 14 \\
\hline 1425 & 354 & 5315 & Basithoh & \\
\hline 1426 & 355 & 5670 & Kabisat & 16 \\
\hline 1427 & 355 & 6025 & Kabisat & 17 \\
\hline 1428 & 354 & 6379 & Basithoh & \\
\hline 1429 & 354 & 6733 & Basithoh & \\
\hline 1430 & 354 & 7087 & Basithoh & \\
\hline 1431 & 354 & 7441 & Basithoh & \\
\hline 1432 & 355 & 7796 & Kabisat & 22 \\
\hline 1433 & 354 & 8150 & Basithoh & \\
\hline 1434 & 355 & 8505 & Kabisat & 24 \\
\hline 1435 & 354 & 8859 & Basithoh & \\
\hline 1436 & 354 & 9213 & Basithoh & \\
\hline 1437 & 354 & 9567 & Basithoh & \\
\hline 1438 & 355 & 9922 & Kabisat & 28 \\
\hline 1439 & 354 & 10276 & Basithoh & \\
\hline 1440 & 355 & 10631 & Kabisat & 30 \\
\hline
\end{tabular}

We can conclude from the results of the accumulation in the table that the Kabisat year pattern from 1411 to 1440 is $2,4,8,9,14,16,17,22,24,28,30$. This pattern is closer to the IV pattern. For more details, see the following table. 


\begin{tabular}{cccccccccccc}
\hline Type & \multicolumn{110}{c}{ Kabisat Year } \\
\hline Pattern I & 2 & 5 & 7 & 10 & 13 & 15 & 18 & 21 & 24 & 26 & 29 \\
\hline Pattern II & 2 & 5 & 7 & 10 & 13 & 16 & 18 & 21 & 24 & 26 & 29 \\
\hline Pattern III & 2 & 5 & 8 & 10 & 13 & 16 & 19 & 21 & 24 & 27 & 29 \\
\hline Pattern IV & 2 & 5 & 8 & 11 & 13 & 16 & 19 & 21 & 24 & 27 & 30 \\
\hline $\begin{array}{c}\text { Time Span } \\
(1411-1440)\end{array}$ & 2 & 4 & 8 & 9 & 14 & 16 & 17 & 22 & 24 & 28 & 30 \\
\hline
\end{tabular}

So, in the span of $1411 \mathrm{H}$ to $1440 \mathrm{H}$, the spread pattern of Kabisat years is closer to that of IV. There are 5 years whose leap is the same as pattern IV, namely $2,8,16,24$, and, 30. In addition, there are 6 years whose leap is different from the IV pattern, namely 4, 9, 14, 17, 22, and, 28.

\section{Conclusion}

The Islamic Arithmetic Calendar (Hijriah Istilahi) has 4 different patterns. In the pattern I, the year will be considered a leap (kabisat) if the sum of the accumulated remaining years per year equals or exceeds 12 hours. In pattern II, the year will be considered Kabisat if the amount of accumulated remaining per year exceeds 12 hours. In pattern III, the year will be considered a leap (kabisat) if the amount of accumulated remaining per year exceeds 15 hours. In pattern IV, the year will be considered a leap (kabisat) if the amount of accumulated remaining per year exceeds 16 hours 30 minutes. If 2 years have exceeded this provision, then the Kabisat is in the closest year.

The kabisat year pattern uses the Ministry of Religion's Ephemeris reckoning system based on the Imkan al-Rukyah MABIMS criteria with the headquarters of the Kudus district from 1411 to 1440 , closer to the fourth pattern. There are 5 years whose leap is the same as pattern IV, namely 2, 8, 16, 24, and 30. In addition, there are 6 years whose kabisat is different from the IV pattern, namely 4, 9, 14, 17, 22, and 28.

\section{Bibliography}

Al-Juzairi. “Al-Fiqhu Ala Al-Madzahibi Al-Arba'ah.” In J.I. Beirut: Dar Kutub al-Ilmiah, 2003. An-Nawawi, Imam Abu Zakariya Muhyiddin bin Syarof. “Al-Majmu' Syarh Al-Muhadzab.” In J. VI. Beirut: Dar Kutub al-Ilmiah, 1996. 
Anugraha, Rinto. Mekanika Benda Langit. Yogyakarta: Universitas Gadjah Mada, 2012.

Anwar, Nur. "Belajar Lebih Dari Matematikawan Muslim.” Jurnal Itqan Vol. 8, no. 2 (2017).

Anwar, Syamsul. Hisab Awal Bulan Kamariah. Yogyakarta: Suara Muhammadiah, 2009.

Az-Zuhaili, Wahbah. “Al-Fiqhu Al-Islami Wa Adillatuhu.” In J. II. Beirut: Dar al-Fikr, 1989.

Azhari, Susiknan. Ensiklopedia Hisab Rukyat. Yogyakarta: Pustaka Pelajar, 2005.

Bagheri, Mohammad. "Kushyar Ibn Labban's Scientific Legacy.” In Astronomical Heritage of the Middle East, edited by Sona V Farmanyan, Areg M Mickaelian, J McKim Malville, and Mohammad Bagheri, Vol. 520. Astronomical Society of the Pacific Conference Series, 2019.

Bashori, Muh. Hadi. Penanggalan Islam: Peradaban Tanpa Penanggalan, Inikah Pilihan Kita? Jakarta: PT Elex Media Komputindo, 2013.

Djamaluddin, Thomas. Astronomi Memberi Solusi Penyatuan Umat. Bandung: LAPAN, 2011.

Echols, John M. Kamus Inggris Indonesia. Jakarta: PT. Gramedia, 2005.

Gent, Robert Harry Van. "The Arithmetical or Tabular Islamic Calender." Accessed November 11 , 2020. https://webspace.science.uu.nl/ ${ }^{\sim}$ gent0113/islam/islam_tabcal_variants.htm.

Hidayat, Ehsan. "Penentuan Jumlah Gerhana Matahari Dengan Argumen Lintang Bulan Dan Teori Aritmatika.” MIYAH: Jurnal Studi Islam Vol. 16, no. No. 1 (2020).

Inshafi, Zul Amri Fathinul. "Aplikasi Data Ephemeris Matahari Dan Bulan Berdasarkan Perhitungan Jean Meeus Pada Smartphone Android.” Universitas Islam Negeri Walisongo, 2016.

Jayusman, J. "Wacana Takwim Urfi Dalam Penanggalan Islam.” Jurnal Hukum Islam IAIN Pekalongan 7, no. 2 (2009).

Khazin, Muhyiddin. Ilmu Falak: Dalam Teori Dan Praktik. Yogyakarta: Buana Pustaka, 2008.

Luminet, Jean Pierre. "Ulugh Beg, Prince of Stars.” ArXiv E-Prints, April 2018.

Ma'rufin Sudibyo. Variasi Lokal Dalam Visibilitas Hilal: Observasi Hilal Di Indonesia Pada 2007. 2009. Yogyakarta: Lembaga Pengkajian dan Pengembangan Ilmu Falak RHI, 2012.

Meeus, Jean. Astronomical Alghorithms. Virginia: Willmann-Bell, Inc., 1998.

—. Mathematical Astronomy Morsels. Virginia: Willmann-Bell, Inc., 1997.

Mulyadi, Achmad. "Pemikiran Al-Khawarizmi Dalam Meletakkan Dasar Pengembangan Ilmu Astronomi Islam Pendahuluan Selama Kurang Lebih 14 Abad, Peradaban Islam Dapat Berjaya Di Seantero.” International Journal Ihya 'Ulum Al-Din Vol. 20, no. 1 
(2018).

Munawwir, Ahmad Warson. Al-Munawwir: Kamus Arab Indonesia. Surabaya: Pustaka Progesif, 1997.

Muslifah, Siti. "Upaya Menyikapi Perbedaan Penentuan Awal Bulan Qamariyah Di Indonesia." Azimuth: Journal of Islamic Astronomy Vol. 1, no. 1 (2020).

Musonnif, Ahmad. "Pemikiran Shi'ah Ismailiyah Tentang Kalender Islam (Tinjauan Atas Sistem Kalender Hisabi Dinasti Fatimiyah).” Kontemplasi: Jurnal Ilmu-Ilmu Ushuluddin Vol 4, no. 2 (2016).

Nasir, M Rifa Jamaludin. "Hisab Aritmatik (Kajian Epistemologi Atas Pemikiran Ma’şum Bin Ali Dalam Kitab Bad i'ah Al-Mitsal).” AL-AFAQ: Jurnal Ilmu Falak Dan Astronomi Vol. 1, no. 1 (2019).

Nasution, Hasnah. "Pemikiran Kalam Syi'ah Imamiyah." Analytica Islamica Vol. 4, no. 1 (2015).

Nordin, Anis Nurashikin. "Regenerating Muslim Inventors - The Present Future." 'Ulum Islamiyyah: The Malaysian Journal of Islamic Sciences Vol. 31 (2020).

Rashed, M.G., M.G. Moklof, and Alaa E. Hamza. "Investigation the Arithmetical or Tabular Islamic Calendar.” NRIAG Journal of Astronomy and Geophysics 7, no. 1 (2018).

Rausi, Fathor. "Astrolabe; Instrumen Astronomi Klasik Dan Kontribusinya Dalam Hisab Rukyat.” ElFalaky: Jurnal Ilmu Falak Vol. 3, no. 2 (2019).

RI, Yayasan Penyelenggara Penterjemah Mushaf Al-Quran Departemen Agama. Al-Qur'an Dan Terjemah Juz 1-Juz 30. Surabaya: Terbit Terang, 2002.

Ridhallah, Alaik. "Sistem Penaggalan Baha'i Persfektif Astronomi." AL-AFAQ: Jurnal Ilmu Falak Dan Astronomi Vol. 2, no. 1 (2020).

Riza, Muhammad Himmatur. "Kriteria Kalender Hijriyah Global Tunggal Turki 2016 Perspektif Tim Hisab Rukyat Kementrian Agama RI.” ElFalaky: Jurnal Ilmu Falak 2, no. 1 (2018).

Rofiuddin, Ahmad Adib. "Dinamika Sosial Penentuan Awal Bulan Hijriah Di Indonesia." Istinbath: Jurnal Hukum Dan Ekonomi Islam Vol. 18, no. 2 (2019).

Sado, Arino Bemi. "Imkan Al-Rukyat MABIMS Solusi Penyeragaman Kalender Hijriyah.” Istinbath: Jurnal Hukum Islam Vol. 13, no. 1 (2014).

SS, Noor Ahmad, and Abu Syaiful Mujab. Risalah Syamsul Hilal Juz I. Kudus: Madrasah Tasywiquth Thullab Salafiyah Kudus, n.d.

Syarif, Muh. Rasywan. "Diskursus Perkembangan Formulasi Kalender Hijriah.” ElFalaky: Jurnal Ilmu Falak Vol. 2, no. 1 (2018). 